\title{
Water content, fibres, and herbivory in leaves of two distinct and adjacent tree communities of the Brazilian Atlantic Forest
}

\author{
Aline Alves do Nascimento ${ }^{1,2,3,6}$, Luis Fernando Tavares de Menezes ${ }^{4}$ and Marcelo Trindade Nascimento ${ }^{5}$ \\ Received: 6.6.2016; aceito: 16.01.2017
}

\begin{abstract}
Water content, fibres, and herbivory in leaves of two distinct and adjacent tree communities of the Brazilian Atlantic Forest). The aims of the present study were to verify whether plants from Mussununga differ from those of Mata Alta in relation to herbivory, water content, and fibres, and to test whether plants with lower leaf water content and higher fibres are less attacked by chewing insects. The results indicated that leaf herbivory percentages and fibres were similar between the two communities, although individuals from Mata Alta showed higher leaf water content than individuals from Mussununga. Thus, the herbivory patterns found for these tree communities do not seem to not be influenced by water content and fibres. Other factors (e.g., chemical defenses and/or herbivores) may be acting as main drivers.
\end{abstract}

Keywords: leaf damage area, leaf quality, Mata Alta, Myrtaceae, Mussununga

RESUMO - (Conteúdo de água, fibras e herbivoria em folhas de duas comunidades arbóreas distintas de Mata Atlântica). Os objetivos do estudo foram avaliar se plantas de duas comunidades arbóreas distintas e adjacentes da Mata Atlântica (Mata Alta e Mussununga) diferem em relação à herbivoria e se plantas com maior conteúdo de água ou menor concentração de fibras nas folhas sofrem mais herbivoria. Os resultados indicaram que as duas comunidades estudadas não diferem quanto à porcentagem de herbivoria foliar e fibras, embora indivíduos da Mata Alta apresentem maiores porcentagens de água em suas folhas que indivíduos da Mussununga. Desta forma, o padrão de herbivoria encontrado para as duas comunidades arbóreas parece não ser influenciado pela concentração de fibra e conteúdo de água. Outros fatores (i.e. defesas químicas e/ ou herbívoros) podem estar atuando como principais agentes.

Palavras-chave: dano foliar, Mata Alta, Myrtaceae, Mussununga, qualidade foliar

\section{Introduction}

Herbivory exerts an important selective pressure on plants (Coley et al. 1985) and can positively affect leaf growth and leaf production (Nascimento \& Hay 1993, Nascimento \& Hay 1994). However, high herbivory rates generally have negative effects on the growth, reproduction, and competitive ability of plants, consequently affecting plant community composition (Crawley 1983, Coley \& Barone 1996, Marquis 2004).

Herbivory pressure allows for the evolution of different defense mechanisms (Marquis 1984, Coley et al. 1985), including physical/mechanical defenses, such as thorns (Cooper \& Ginnett 1998) and nonglandular trichomes (Baur et al. 1991, Rodrigues et al. 2012, Fürstenberg-Hägg et al. 2013), and chemical defenses, such as the production of a series of toxins and defense proteins that target the physiological processes of insects, in an attempt to repel or intoxicate herbivores (Coley \& Barone 1996, Mello \& Silva- Filho 2002, Gullan \& Cranston 2007, Trigo et al. 2012). In addition to defensive mechanisms, the nutritional quality of leaf tissues also affects the feeding of herbivorous insects (Coley 1987, Marquis 2012, Cárdenas et al. 2014), while low water and

1. Parte da Dissertação de Mestrado do primeiro Autor

2. Universidade Federal do Espírito Santo, Departamento de Ciências Agrárias e Biológicas, Programa de Pós-Graduação em Biodiversidade Tropical, Laboratório de Ecologia de Restinga e Mata Atlântica, Rodovia BR 101 Norte, Km 60, Litorâneo, 29932-540 São Mateus, ES, Brasil

3. Universidade Estadual do Norte Fluminense Darcy Ribeiro, Centro de Biociências e Biotecnologia, Laboratório de Ciências Ambientais, Av. Alberto Lamego, 2000, Parque Califórnia, 28013-602 Campos dos Goytacazes, RJ, Brasil

4. Universidade Federal do Espírito Santo, Departamento de Ciências Agrárias e Biológicas, Laboratório de Ecologia de Restinga e Mata Atlântica, Rodovia BR 101 Norte, Km 60, Litorâneo, 29932-540 São Mateus, ES, Brasil

5. Universidade Estadual do Norte Fluminense Darcy Ribeiro, Centro de Biociências e Biotecnologia, Laboratório de Ciências Ambientais, Av. Alberto Lamego, 2000, Parque Califórnia, 28013-602 Campos dos Goytacazes, RJ, Brasil

6. Corresponding author: line.uenf@gmail.com 
nitrogen content in leaves may lead to a decrease in the preference and performance of chewing insects (Basset 1991, Loaiza et al. 2011, Marquis 2012).

In resource-limited environments, slow-growing species invest more resources in producing immobile defenses, such as lignin or total phenols, displaying lower herbivory rates (Coley 1983, Coley et al. 1985, Endara \& Coley 2011). Tree species adapted to these environments exhibit lower capacity to absorb nutrients and to perform photosynthesis (Chapin 1980). Thus, for these plants, it is probably more costly to replace lost parts than to defend them (Coley et al. 1985, Fine et al. 2004, 2006, Agrawal 2006, Fine \& Mesones, 2011). Although, many studies dealing with herbivory in the Atlantic rainforest are available, most are related to the community level or seed/fruit predation (Souza et al. 2013, Rossetti et al. 2014; Galetti et al. 2015, Corrêa et al. 2016). Leaf herbivory studies considering functional characteristics of Atlantic forest trees in contrasting chemical and physical soils have not yet been performed. Therefore, the seasonally dry forest in the Northern area of the state of Espírito Santo, Brazil, can be considered an ideal forest formation to assess the relationship between herbivory, nutritional aspects and chemical defenses, because it displays two distinct and peculiar phytophysiognomies under the same climatic condition: the Mussununga, with sandy soils and lower diversity, and the Mata Alta, with clayey soils and higher floristic diversity (Simonelli et al. 2008). Mata Alta soils and humus are more nutrient rich (with a lower $\mathrm{C} / \mathrm{N}$ ratio) than Mussununga soils (Garay et al. 2003, 2016). Myrtaceae is recognised as one of the most important families in both types of forests, both in terms of the number of species and individuals (Jesus \& Rolim 2005, Simonelli et al. 2008, Giaretta et al. 2016). Furthermore, certain species of this family produce secondary compounds, such as terpenoids and phenols (Cooper 2001, Chaieb et al. 2007, Keszei et al. 2010) and display physical defenses, like leaf hardness, which provides them not only with chemical resistance, but also mechanical resistance to leaf-chewing insects (Sanson et al. 2001). In this context, we expected to find that Mussununga vegetation plants, with lower water content and higher fibre content, should therefore be less attacked by herbivorous insects compared to Mata Alta plants, which have higher water content and lower fibres. Only plants of the Myrtaceae family were investigated, due to their representativeness and the abundance of individuals in the studied areas. The use of plants from the same family also allows for control regarding phylogenetical aspects.

\section{Material and methods}

The study was performed in two areas with distinct physiognomies located within the Vale Natural Reserve (Reserva Natural Vale - RNV) in Linhares, state of Espírito Santo, Brazil, between the parallels $19^{\circ} 05^{\prime}$ and $19^{\circ} 18^{\prime} \mathrm{S}$ and meridians $39^{\circ} 45^{\prime}$ and $40^{\circ} 19^{\prime} \mathrm{W}$. A 1-ha permanent plot was applied in two areas: the Mata Alta $\left(19^{\circ} 09^{\prime} 14.2^{\prime \prime} \mathrm{S}\right.$ and $\left.040^{\circ} 02^{\prime} 0.004^{\prime \prime} \mathrm{W}\right)$ and Mussununga forests $\left(19^{\circ} 09^{\prime} 078^{\prime \prime S}\right.$ and $\left.040^{\circ} 02^{\prime} 197^{\prime \prime} \mathrm{W}\right)$. These areas were selected considering their different soil characteristics (clay soil at Mata Alta and sandy soil at Mussununga) and physiognomies (closed canopy at Mata Alta; open canopy at Mussununga). Mata Alta is more representative of the lowland forest and corresponds to approximately $70 \%$ of the total RNV area, of which only $8 \%$ is occupied by secondary forest. It is characterised by closed canopy trees, reaching up to $40 \mathrm{~m}$ in height, and a poorly developed understory. Its soils are classified as clayey or clayeysandy (Peixoto et al. 2008, Rolim et al. 2016b), being dystrophic yellow podzol or yellow argisol (ultisol), and are characterised by differences in grain size with depth and low fertility (Garay et al. 2003).

The Mussununga forest is surrounded by the Mata Alta forest, forming an enclave within the latter (Peixoto et al. 2008, Rolim et al. 2016b), and occupies $7.9 \%$ of the RNV area (Peixoto et al. 2008). It is composed of trees with less dense canopies, allowing higher light penetration to the soils. Soils are classified as hydromorphic podzol with a sandy texture, with a shallow water table that rises to the surface during certain times of the year (Garay et al. 2003, Simonelli et al. 2008, Saporetti-Junior et al. 2012, Rolim et al. 2016b). The trees reach approximately $10 \mathrm{~m}$ in height, although some emergent species can grow up to $20 \mathrm{~m}$ (Simonelli et al. 2008, Rolim et al. 2016b). This forest displays low species richness in comparison to Mata Alta and has a lower abundance of xerophile elements, lianas and bromeliads, with characteristics similar to those of the restinga forest (coastal sandy-soil forests) (Garay et al. 2003, Simonelli et al. 2008).

Mata Alta shows higher species diversity $\left(\mathrm{H}^{\prime}=5.04\right.$ nats $\left./ \mathrm{sp} ; \mathrm{DBH} \geq 10 \mathrm{~cm}\right)$ when compared to Mussununga $\left(\mathrm{H}^{\prime}=3.36\right.$ nats $\left./ \mathrm{sp} ; \mathrm{DBH} \geq 5 \mathrm{~cm}\right)$. The Shannon diversity index for Mata Alta is one of the highest ever recorded in the Atlantic Forest (Jesus \& Rolim 2005). A similarity analysis using the Jaccard index based on species lists published by Peixoto et al. (2008), Simonelli et al. (2008), and Jesus \& Rolim (2005) indicates that the similarity between 
the tree species of Mata Alta and Mussununga is low $(\mathrm{SJ}=0.067)$. However, at the family level, Myrtaceae shows high representativeness in both physiognomies, being the family with the highest number of species in both Mata Alta (14\%) (Jesus \& Rolim, 2005) and Mussununga (24\%) (Simonelli et al. 2008).

The soils that dominate the Mata Alta and Mussununga regions are, in general, low fertility homogeneous soils, with a sandy surface horizon unfavourable for nutrient retention. Therefore, organic matter originating from the vegetation may be essential for the maintenance of soil structure and fertility (Garay et al. 2003). Total carbon in the hemiorganic A12 horizon of the soil in the RNV is $0.72 \%$ at Mata Alta and $1.16 \%$ at Mussununga, whereas $\mathrm{N}$ concentrations are $0.08 \%$ at Mata Alta and $0.07 \%$ at Mussununga, with a $\mathrm{C} / \mathrm{N}$ ratio of 8.9 for Mata Alta and 16.9 for Mussununga (Garay et al. 2003).

The climate in the region is classified as type Aw according to the Köppen climate classification (Peixoto et al. 2008), i.e. hot and humid, marked by seasonality, with a wet season in the summer (October to March) and a dry season in the winter (April to September). The mean annual rainfall is of $1.227 \mathrm{~mm}$ year ${ }^{-1}$, with mean temperature ranging from $20^{\circ} \mathrm{C}$ to $26^{\circ} \mathrm{C}$ (Rolim et al. 2016a). The native vegetation in the state of Espírito Santo is generally classified as being a lowland dense rainforest (RADAMBRASIL 1987). However, some studies have analysed the vegetation based on functional traits related to seasonal aspects and have categorized it as being a lowland seasonal semideciduous forest or semideciduous rainforest (Peixoto \& Gentry 1990) or lowland seasonal evergreen forest (Rolim et al. 2016a).

Tagged Myrtaceae trees of the understory between 8 and $10 \mathrm{~m}$ in height were randomly selected for leaf collection in the 1-ha plots of each forest type, regardless of species. Six to 10 mature leaves from each selected tree in both areas were collected in August 2010 and February 2011 for subsequent herbivory and functional traits analyses. Mature leaves were considered as being the leaf below the fourth leaf counting from the apex to the base of the branch, being dark-green in coloring (Nascimento \& Proctor 2001, Nascimento at al. 2011). The total leaf area consumed by herbivores (leaf-chewing insects) was visually estimated using a system of seven classes of percentile damage ( 1 = absence of damage by herbivory; $2=$ ]0,5]; $3=$ ]5,10]; $4=$ ]10,25]; $5=$ ]25,50]; $6=] 50,75]$; and $7=175,100]$ ). The mean herbivory rate for each tree was calculated by multiplying the number of damaged leaves within each herbivory class by the mean interval of classes into which the leaves were classified, and subsequently dividing the result by the total leaf samples (Nascimento \& Proctor 2001, Nascimento at al. 2011).

$$
\text { Percentage of herbivory }=\Sigma(\text { ni x i }) / \mathrm{N}
$$

Where,

$\mathrm{Ni}$ : number of mature leaves within the herbivory class;

I: mean interval of the herbivory class;

$\mathrm{N}$ : total number of sampled mature leaves.

The collected leaves (6 to 10) were separated from the branch, placed in plastic bags and Styrofoam boxes and taken to the laboratory, where they were weighed using a semi-analytical scale. The leaves were subsequently left in a forced-air oven at $105^{\circ} \mathrm{C}$ until reaching constant weight. Water content was calculated by finding the difference between the dry weight and the initial weight and multiplying the result by 100 , to obtain percentage values (Allen 1989).

The chemical analyses for the determinations of the neutral detergent fibre (NDF), acid detergent fibre (ADF), cellulose (CEL) and lignin (LIG) were performed by sequential analysis at the Laboratory of Animal Science and Animal Nutrition (Laboratório de Zootecnia e Nutrição Animal - LZNA) of the Agricultural Science and Technology Centre/State University of the North of Rio de Janeiro (Centro de Ciências e Tecnologias Agropecuárias/Universidade Estadual do Norte Fluminense Darcy Ribeiro, CCTA/ UENF), following the method described by Van Soest et al. (1991), using $0.5 \mathrm{~g}$ of the dry and pulverised plant material. Lignin content was determined by the $72 \%$ sulphuric acid method, followed by incineration of the obtained residue at $550{ }^{\circ} \mathrm{C}$ for $3 \mathrm{~h}$. Cellulose content was determined by calculating the difference between ADF and lignin. The NDF includes cellulose, hemicellulose, and lignin as its main components, in addition to heat-damaged proteins, cell wall proteins, and minerals (ashes). In contrast, the ADF consists primarily of cellulose and lignin (lignocellulose) and heat-damaged proteins, with small amounts of cell wall proteins and insoluble minerals (ashes).

Description of the statistical analyses - The MannWhitney U-test was used to compare herbivory rates and water and fibre content median values between the investigated areas. The analyses were not performed to the species level because of the low sampling of species common to both areas. 
A linear regression analysis was performed to assess the relationship between herbivory, fibre concentrations and water content in the sampled from Myrtaceae species from each forest type. All analyses were performed using the $\mathrm{R}$ software package, version 3.2.4 revised (2016).

\section{Results and Discussion}

The percentage of leaf areas lost to herbivores did not differ between Mata Alta and Mussununga (MannWhitney U-test, $\mathrm{p}=0.29$ ), with mean values ranging from 8 to $11 \%$ (table 1 ). These values are close to the upper limit recorded for humid tropical forests (ca. $15 \%$ ), evaluated using a similar methodology (Sterck et al. 1992, Nascimento \& Proctor 2001, Cárdenas et al. 2014). Cases of individuals with extreme leaf areas lost by herbivory ( $>25 \%$ ) were rare (less than $2 \%$ of trees) in both sampled areas (figure 1).

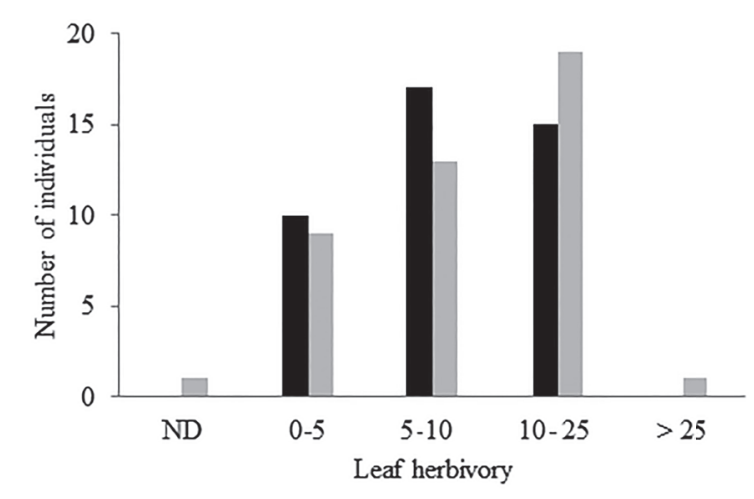

Figure 1. Variation in leaf herbivory rates (\%) in Myrtaceae trees sampled from Mata Alta and Mussununga. $\mathrm{ND}=$ no damage. Mata Alta (back bar) and Mussununga (gray bar). $\mathrm{N}=43$.

Significant differences were observed between Mata Alta and Mussununga Myrtaceae species relative leaf water (Mann-Whitney U-test, $p=0.03$ ), with leaves from the former showing significantly higher values compared to leaves from the latter (table 1), as expected, since Mussununga has a sandy soil (Garay et al. 2003, 2016).

The analysed fibre concentrations (NDF, ADF, CEL and LIG) did not differ significantly between the areas (Mann-Whitney U-test, $\mathrm{p}>0.05$ ) (table 1). Although fibre contents in leaves may act as a barrier regarding the use of these leaves as a food source (Coley, 1983; Clissold et al. 2009, Cárdenas et al. 2014), the present study did not corroborate this statement, since simple linear regressions performed between herbivory and fibres (ADF, NDF, CEL and
LIG) indicated no significant relationship between herbivory and any of the variables (figure 2).

Plants display a combination of defense systems that involve physical and chemical barriers and/or the recruitment of predators and parasitoids that prevent or hinder herbivores from completely exploring their host plants (Rasmann \& Agrawal 2009, Marquis 2012). It is well known that leaf fibre content may act as a barrier
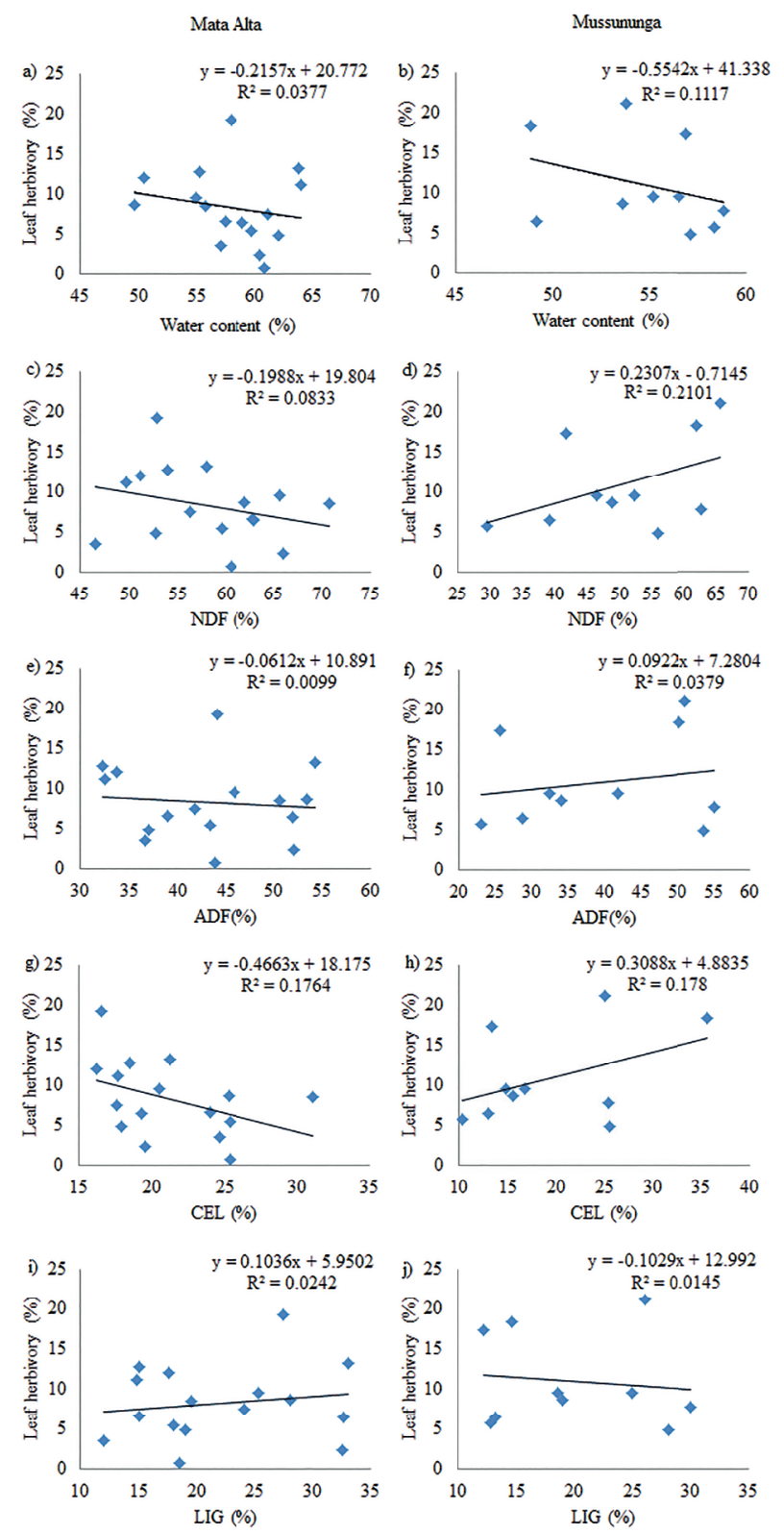

Figure 2. Simple linear regressions between herbivory and water content neutral detergent fibre (NDF), acid detergent fibre (ADF), cellulose (CEL) and lignin (LIG) in the leaves of the investigated Myrtaceae species $(\mathrm{DBH}>10 \mathrm{~cm})$ in the understory of the Mata Alta $(\mathrm{N}=16$ species, a, c, e, g and i) and Mussununga $(\mathrm{N}=10$ species, b, d, f, h and j) areas located in the RNV, Linhares, Espírito do Santo State, Brazil. 


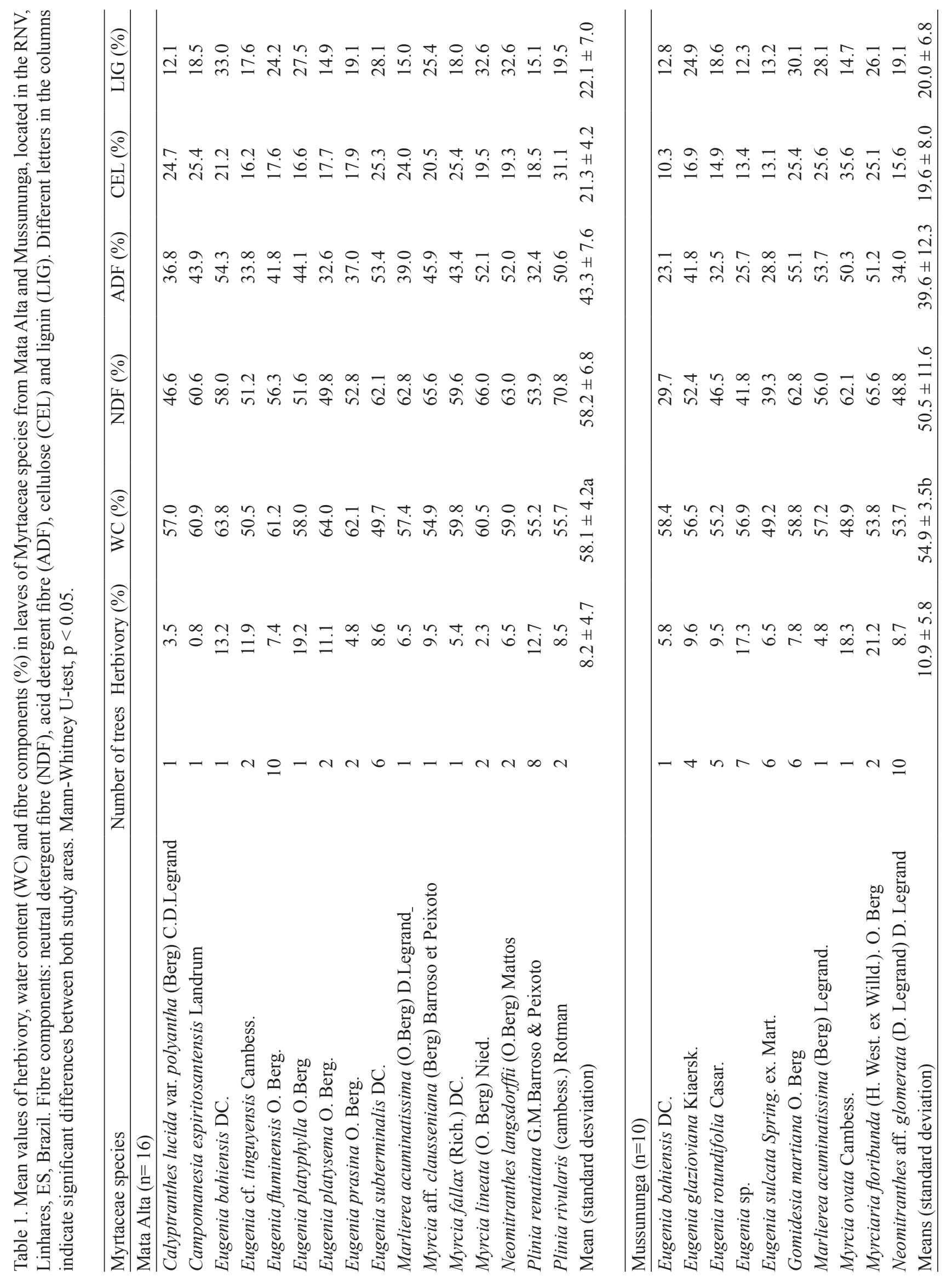


regarding the use of leaves as a food source against small mammals and insects (Coley 1983, Clissold et al. 2009, Cárdenas et al. 2014). Several studies have found significant negative correlations between leaf herbivory and fibre, cellulose and lignin concentrations (Coley 1983, Lacerda et al. 1986, Coley 1987, Coley \& Barone 1996). Sinclair \& Hughes (2008) studied 88 Myrtaceae species and observed that the presence of mining insects was positively and significantly correlated to species presenting thinner leaves and high phenol concentrations. These authors also found a marginal significance for specific leaf area and water content, as well as no significant correlation for leaf area, hemicellulose or tenacity. In the present study, Mata Alta trees showed higher water content than trees from Mussununga, suggesting that environmental conditions such as soil characteristics are the main driving factor, as observed by Marquis et al. (2002). The lack of differences in herbivory percentages between these forest types and the non-significant relationships between herbivory and fibre and water content suggest that attacks by herbivorous insects can be limited by other chemical leaf aspects, such as sugars and nitrogen content, among others, as also suggested by Cornelissen \& Fernandes (2001).

The hypothesis that plants with lower water and/ or higher fibre content are less attacked by chewing insects was, thus, not accepted. Although Myrtaceae trees from Mata Alta had higher water content in leaves when compared to Mussununga trees, herbivory values were similar. Thus, the herbivory pattern in these forest types seems to not to be strongly influenced by fibre concentrations and relative water content, suggesting that other factors (i.e. chemical defenses and/or herbivores) might be acting as main agents.

\section{Acknowledgments}

The authors would like to thank the staff of the Vale Natural Reserve (Reserva Natural Vale - RNV) for logistic support; the Brazilian Federal Agency for Support and Evaluation of Graduate Education (Coordenação de Aperfeiçoamento de Pessoal de Nível Superior - CAPES) for the masters' scholarship granted to Aline Alves do Nascimento; the National Council for Scientific and Technological Development (Conselho Nacional de Desenvolvimento Científico e Tecnológico - CNPq) for the research productivity scholarships granted to Marcelo Trindade Nascimento and Luis Fernando Tavares de Menezes; and Alberto Magno Fernandes, Ricardo Augusto Mendonça Vieira, and Cláudio Teixeira Lombardi, from the Laboratory of Animal Science and Animal Nutrition at the Darcy Ribeiro State University of the North of Rio de Janeiro (Universidade Estadual do Norte Fluminense Darcy Ribeiro - UENF) for the assistance provided with the chemical analyses; and Tito Cesar Marques de Almeida, of Laboratory of Aquatic Ecology from the University of Vale do Itajai and Inácio Abreu Pestana at the Darcy Ribeiro State University of the North of Rio de Janeiro for aiding in the statistical analyses.

\section{Literature cited}

Agrawal, A.A. 2006. Macroevolution of plant defense strategies. Trends in Ecology and Evolution 22: 103-109.

Allen, S.E. 1989. Chemical analysis of ecological materials. Blackwell Scientific Publications, Oxorf.

Basset, Y. 1991. Influence of leaf traits on the spatial distribution of insect herbivores associated with an overstorey rainforest tree. Oecologia 87: 388-393.

Baur, R., Binder, S. \& Benz, G. 1991. Nonglandular leaf trichomes as short-term inducible defense of the grey alder, Alnus incana (L.), against the chrysomelid beetle, Agelastica alni L. Oecologia 87: 219-226.

Chaieb, K., Hajlaoui, H., Zmantar, T., Kahla-Nakbi, A.B., Rouabhia, M., Mahdouani, K. \& Bakhrouf, A. 2007. The chemical composition and biological activity of clove essential oil, Eugenia caryophyllata (Syzigium aromaticum L. Myrtaceae): a short review. Phytotherapy Research 21: 501-506.

Cárdenas, R.E., Valencia, R., Kraft, N.J.B., Argoti, A. \& Dangles, O. 2014. Plant traits predict inter- and intraspecific variation in susceptibility to herbivory in a hyperdiverse Neotropical rain forest tree community. Journal of Ecology 102: 939-952.

Chapin, F.S. III. 1980. The mineral nutrition of wild plants. Annual Review of Ecology and Systematics 11: 233-260.

Clissold, F.J., Sanson, G.D., Read, J. \& Simpson, S.J. 2009. Gross vs. net income: How plant toughness affects performance of and insect herbivore. Ecology 90: 3393-3405.

Coley, P.D. 1983. Herbivory and defensive characteristics of tree species in lowland tropical forest. Ecological Monographs 53: 209-233.

Coley, P.D., Bryan, J.P. \& Chapin, F.S. III. 1985. Resource availability and plant antiherbivore defense. Science 230: 895-899.

Coley, P.D. 1987. Interspecific variation in plant antiherbivore properties: the role of habitat quality and rate of disturbance. New Phytologist 106: 251-263.

Coley, P.D. \& Barone, J.A. 1996. Herbivory and plant defenses in tropical forests. Annual Review of Ecology and Systematics 27: 305-335. 
Cooper, P.D. 2001. What physiological processes permit insects to eat Eucalyptus leaves? Austral Ecology 26: 556-562.

Cooper, S.M. \& Ginnett, T.F. 1998. Spines protect plants against browsing by small climbing mammals. Oecologia 113: 219-221.

Cornelissen, T.G. \& Fernandes, G.W. 2001. Defence, growth and nutrient allocation in the tropical shrub Bauhinia brevipes (Leguminosae). Austral Ecology 26: 246-253.

Corrêa, M.M., Silva, P.S. D., Wirth, R., Tabarelli, M. \& Leal, I. R. 2016. Foraging activity of leaf-cutting ants changes light availability and plant assemblage in Atlantic forest. Ecological Entomology 41: 442-450.

Crawley, M.J. 1983. Herbivory: The dynamics of animalplant interactions. Blackwell Scientific Publications, Oxford.

Endara, M.J. \& Coley, P.D. 2011. Evolutionary ecology of plant defences. The resource availability hypothesis revisited: a meta-analysis. Functional Ecology 25: 389-398.

Fine, P.V.A., Mesones, I. \& Coley P.D. 2004. Herbivores promote habitat specialization by trees in Amazonian forests. Science 305: 663-665.

Fine, P.V.A., Miller, Z.J., Mesones, I., Irazuzta, S., Appel, H.M., Stevens, M.H.H., Sääksjärvi, I; Schultz, J.C. \& Coley, P.D. 2006. The growth-defense trade-off and habitat specialization by plants in amazonian forests. Ecology 87: S150-S162.

Fine, P.V.A. \& Mesones, I. 2011. The Role of Natural Enemies in the Germination and Establishment of Pachira (Malvaceae) Trees in the Peruvian Amazon. Biotropica 43: 265-269.

Fürstenberg-Hägg, J., Zagrobelny, M. \& Bak, S. 2013. Plant defense against insect herbivores. International Journal of Molecular Sciences 14: 10242-10297.

Galetti, M., Guevara, R., Galbiati, L.A., Neves, C.L., Rodarte, R.R. \& Mendes, C.P. 2015. Seed Predation by Rodents and Implications for Plant Recruitment in Defaunated Atlantic Forests. Biotropica 47: 521-525.

Garay, I., Kindel, A., Louzada, M.A.P. \& Santos, R.D. 2003. Diversidade funcional dos solos na Floresta Atlântica de Tabuleiros. In: I. Garay \& C.M. Rizzini (eds.). A Floresta Atlântica de Tabuleiros: diversidade funcional da cobertura arbórea ed. 1, v. 1, Vozes, Rio de Janeiro, pp. 16-26.

Garay, I., Finotti, R., Kindel, A, Louzada, M, Rizzini, M.C. \& Pérz, D.V. 2016. Formas de húmus como indicador funcional de ecossistemas emergentes na Floresta de Tabuleiro. In: S.G. Rolim, L.F.T. Menezes, Srbek-Araujo, Ana Carolina (eds.). Floresta Atlântica de Tabuleiro: diversidade e endemismo na Reserva Natural Vale. Rona, Belo Horizonte. pp. 101-127.
Giaretta, A., Tuler, A.C., Souza, M. C., Valdemarin, K.S., Mazine, F.F. \& Peixoto, A.L. 2016. Diversidade de Myrtaceae na Reserva Natural Vale. In: S.G. Rolim, L.F.T. Menezes, Srbek-Araujo, Ana Carolina (eds.). Floresta Atlântica de Tabuleiro: diversidade e endemismo na Reserva Natural Vale. Rona, Belo Horizonte. pp. 247-257.

Gullan, P.J. \& Cranston, P.S. 2007. Os insetos: um resumo de entomologia. Roca, São Paulo.

Jesus, R.M. \& Rolim, S.G. 2005. Fitossociologia da Mata Atlântica de Tabuleiro. Boletim Técnico SFI, n 19.

Loaiza, V., Jonas, J. L. \& Joern, A. 2011. Grasshoppers (Orthoptera: Acrididae) select vegetation patches in local-scale responses to foliar nitrogen but not phosphorus in native grassland. Insect Science 18: 533-540.

Keszei, A., Brubaker, C.L., Carter, R., Köllner, T., Degenhardt, J. \& Foley, W.J. 2010. Functional and evolutionary relationships between terpene synthases from Australian Myrtaceae. Phytochemistry 71: 844-852.

Lacerda, L.D., Jose, D.M, Rezende, C.E, Francisco, M.C.F.F., Wasserman, J. \& Martins, J. C. 1986. Leaf chemical characteristics affecting herbivory in a New World Mangrove Forest. Biotropica 18: 350-355.

Marquis, R.J. 1984. Leaf herbivores decrease fitness of a tropical plant. Science 226: 537-539.

Marquis, R.J., Morais, H.C. \& Diniz, I.R. 2002. Interactions among Cerrado plants and their herbivores: Unique or typical? In: P. S. Oliveira \& R. J. Marquis (eds.). The Cerrados of Brazil. Columbia University Press, New York, pp. 306-328.

Marquis, R.J. 2004. Herbivores Rule. Science 305: 619-621.

Marquis, R.J. 2012. Uma abordagem geral das defesas das plantas contra ação dos herbívoros. In: K. Del-Claro \& H.M. Torezan-Silingardi (eds.). Ecologia das Interações Planta-animais: uma abordagem ecológico-evolutiva. Technical Books, Rio de Janeiro, pp. 55-66.

Mello, M.O. \& Silva-Filha, M.C. 2002. Plant-insect interactions: an evolutionary arms race between two distinct defense mechanisms. Brazilian Journal of Plant Physiology 14: 71-81.

Nascimento, A.A., Vieira, A.F., Silva, A.P., Villela, D.M. \& Nascimento, M.T. 2011. Herbivoria foliar de Xylopia sericea St. Hil. (Annonaceae) em sub-bosque de plantio de Eucalipto e de Mata Atlântica. Scientia Forestalis 39: 77-86.

Nascimento, M.T. \& Hay, J.D. 1993. Intraspecific variation in herbivory on Metrodorea pubescens (Rutaceae) in two forest types in Central Brazil. Revista Brasileira Biologia 53: 143-153.

Nascimento, M.T. \& Hay, J.D. 1994. The impact of simulated folivory on juveniles of Metrodorea pubescens (Rutaceae) in a gallery forest near Brasilia, Federal District, Brazil. Journal of Tropical Ecology 10: 611-620. 
Nascimento, M.T. \& Proctor, J. 2001. Leaf herbivory on three species in a monodominant and two other terra firme forests on Maracá Island, Brazil. Acta Amazônica 31: 27-38.

Peixoto, A.L. \& Gentry, A. 1990. Diversidade e composição florística da mata de tabuleiro na Reserva Florestal de Linhares (ES - Brasil). Revista brasileira de Botânica 13: 19-25.

Peixoto, A.L., Silva, I.M., Pereira, O.J., Simonelli, M., Jesus, R.M. \& Rolim, S.G. 2008. Tabuleiro Forests North of the Rio Doce: Their representation in the Vale do Rio Doce Natural Reserve, Espírito Santo, Brazil. In: W.W. Thomas (ed.). The Atlantic Costal Forest of Northeastern Brazil. The New York Botanical Garden Press, New York, pp.313-344.

R Development core team. 2007. R: A language and environment for statistical computing. R Foundation for Statistical Computing, Vienna, Austria. Available in http://www.R- project.org (acess in 20-VI-2016).

RADAMBRASIL. 1987. Levantamento de Recursos Naturais, v. 34, Folha SE 24-Rio Doce, Rio de Janeiro.

Rasmann, S. \& Agrawal, A.A. 2009. Plant defense against herbivory: progress in identifying synergism, redundancy, and antagonism between resistance traits. Current Opinion in Plant Biology 12: 473-478.

Rodrigues, D., Souza, C.R., Aguiar, R.W.S., Melo, A.V., Silva, J.C., Ootani, M.A. \& Cruz, W.P. 2012. Tricomas conferem resistência contra herbivoria de Cerotoma arcuata em cultivares de soja. Agroecossistemas 4: 33-39.

Rolim, S.G., Ivanauskas, N.M. \& Engel, V.L. 2016a. As Florestas de Tabuleiro do Norte do Espírito Santo são Ombrófila ou Estacionais? In: S. G. Rolim, L.F.T. Menezes, Srbek-Araujo, Ana Carolina (eds.). Floresta Atlântica de Tabuleiro: diversidade e endemismo na Reserva Natural Vale. Rona, Belo Horizonte, pp. 47-60.

Rolim, S.G, Peixoto, A.L. Pereira, O.J., Araujo, D.S.D., Nadruz M. Siqueira, G. \& Menezes, L.F.T. 2016b. Angiospermas da Reserva Natural Vale, na Floresta Atlântica do norte do Espírito Santo. In: S.G. Rolim, L.F.T. Menezes, Srbek-Araujo, Ana Carolina (eds.). Floresta Atlântica de Tabuleiro: diversidade e endemismo na Reserva Natural Vale. Rona, Belo Horizonte, pp. 167-230.
Rossetti, M.R., González, E., Salvo, A. \& Valladares, G. 2014. Not all in the same boat: trends and mechanisms in herbivory responses to forest fragmentation differ among insect guilds. Arthrop-Plant Interactions 8: 593-603.

Sanson, G., Read, J., Aranwela, N., Clissold, F. \& Peeters, P. 2001. Measurement of leaf biomechanical properties in studies of herbivory: Opportunities, problems and procedures. Austral Ecology 26: 535-546.

Saporetti-Junior, A.W., Schaefer, C.E.G.R., Souza, A.L., Soares, M.P., Araujo, D.S.D. \& Meira Neto, J.A.A. 2012. Influence of soil physical properties on plants of the Mussununga ecosystem, Brazil. Folia Geobotanica (Pruhonice) 47: 29-39.

Simonelli, M., Souza, A.L.S., Peixoto, A.L. \& Silva, A.F. 2008. Floristic Composition and Structure of the Tree Component of a Muçununga Forest in the Linhares Forest Reserve, Espírito Santo, Brazil. In: W.W. Thomas (ed.). The Atlantic Costal Forest of Northeastern Brazil. The New York Botanical Garden Press, New York. pp. 351-370.

Sinclair, R.J. \& Hughes, L. 2008. Leaf mining in the Myrtaceae. Ecological Entomology 33: 623-630.

Souza, D.G., Santos, B.A., Wirth, R., Leal, I.R. \& Tabarelli, M. 2013. Community-Level Patterns of Insect Herbivory in a Fragmented Atlantic Forest Landscape. Environmental Entomology 42: 430-437.

Sterck, F., van der Meer, P. \& Bongers, F. 1992. Herbivory in two rain forest canopies in French Guyana. Biotropica 24: 97-99.

Trigo, J.R., Pareja, M. \& Massuda, K.F. 2012. O papel das substâncias químicas nas interações entre plantas e insetos herbívoros. In: K. Del-Claro \& H.M. TorezanSilingardi, (eds.). Ecologia das Interações Plantaanimais: uma abordagem ecológico-evolutiva. Technical Books, Rio de Janeiro, pp. 69-88.

Van Soest, P.J., Robertson, J.B. \& Lewis, B.A. 1991. Symposium: Carbohydrate methodology, metabolism, and nutritional implications in dairy cattle. Journal of the Dairy Science 74: 3583- 3597. 